\title{
Analisi Perbandingan Kinerja Jalan T. Iskandar, Ulee Kareng, B.Aceh Pada Saat Pademi dan Normal
}

\author{
Taslimul Haq ${ }^{1}$ Ruhdi Faisal ${ }^{2}$ Fitrika Mita Suryani $^{3}$ Juliana Fisaini $^{4}$ \\ 1,2,3,4 Jurusan Teknik Sipil, Universitas Syiah Kuala, Banda Aceh 23111, Indonesia \\ Email: ${ }^{2}$ ruhdi.faisal@unsyiah.ac.id
}

\begin{abstract}
Teuku Iskandar road is one of the roads that is easily accessible by people living around Aceh Besar which is directly adjacent to Banda Aceh City. Teuku Iskandar road is included in the Primary Arterial Road type 2 lanes 2 undivided directions (2/2 UD) with a road length of 3,802 kilometers and a road body width of 8 meters with an effective shoulder width of 0.5 meters. Based on the First Dictum letter a, the Instruction of the Minister of Home Affairs Number 31 of 2021 concerning the Implementation of Level 4 Community Activity Restrictions (PPKM) to inhibit the spread of diseases caused by Corona Virus Disease 2019 (Covid-19). In August 2021, Banda Aceh City is included in the red zone so that PPKM level 4 is applied. The purpose of this research is to find out traffic movements before and when PPKM level 4 is treated for B. Aceh City. The method used to analyze the performance of the road segment is to use the Indonesian Road Capacity Manual (MKJI), especially for urban roads. The data parameters needed to evaluate road performance are secondary data in the form of traffic volume, road capacity, RVK (capacity volume ratio), free flow speed and travel speed. The survey was conducted for 3 (three) days a week, namely Monday (16 August 2021), Wednesday (18 August 2021), and Sunday (15 August 2021) at peak hours in the morning and evening, namely 07.00-09.00 WIB and 17.0019.00 WIB. . After data processing, Monday (16 August 2021) at 17.00-18.00 WIB is the highest traffic volume of 1645.7 pcu/hour, capacity of 2737.37 pcu/hour, $R V K=0.60$. Meanwhile, Muzwar's research in 2017 found RVK $=0.60$. This means that PPKM level 4 which was implemented in B. Aceh City has an effect on reducing vehicle movement. Considering that usually the movement of vehicles in the city, there should be an increase in the movement of traffic flow every year.
\end{abstract}

Keywords: MKJI, Kinerja Jalan, T.Iskandar, TVK, Covid-19, PPKM Level 4

\begin{abstract}
Abstrak
Jalan Teuku Iskandar merupakan salah satu jalan yang mudah diakses oleh masyarakat yang tinggal di seputaran Aceh Besar yang berbatasan langsung dengan Kota Banda Aceh. Jalan Teuku Iskandar termasuk kedalam jalan Arteri Primer bertipe 2 lajur 2 arah tak terbagi (2/2 UD) dengan panjang jalan 3,802 kilometer dan lebar badan jalan 8 meter dengan lebar bahu efektif 0,5 meter. Berdasarkan Diktum Kesatu huruf a Instruksi Menteri Dalam Negeri Nomor 31 Tahun 2021 tentang Pemberlakuan Pembatasan Kegiatan Masyarakat (PPKM) Level 4 untuk menghambat penyebaran penyakit yang disebabakan oleh Corona Virus Disease 2019 (Covid-19). Pada bulan Agustus 2021, Kota Banda Aceh termasuk dalam zona merah sehingga diberlakukan PPKM level 4. Adapaun tujuan penelitian ini adalah ingin mengetahui pergerakan lalu-lintas sebelum dan pada saat diperlakukan PPKM level 4 untuk Kota B.Aceh. Metode yang digunakan untuk menganalisa kinerja ruas jalan adalah menggunakan Manual Kapasitas Jalan Indonesia (MKJI) khususnya untuk jalan perkotaan. Parameter data yang diperlukan untuk mengevaluasi kinerja jalan adalah data sekunder berupa volume lalu-lintas, kapasitas jalan, RVK (rasio volume kapasitas) kecepatan arus bebas dan kecepatan tempuh. Survei dilakukan selama 3 (tiga) hari dalam satu minggu yakni hari Senin (16 Agustus 2021), Rabu (18 Agustus 2021), dan Minggu (15 Agustus 2021) pada jam puncak pagi dan sore yaitu 07.00-09.00 WIB dan 17.00-19.00 WIB. Setelah dilakukan pengolahan data, Senin (16 Agustus 2021) pukul 17.00-18.00 WIB merupakan volume lalu-lintas tertinggi sebesar 1645,7 smp/jam, kapasitas sebesar 2737,37 smp/jam, RVK = 0,60. Sedangkan penelitian Muzwar pada tahun 2017 mendapatkan hasil RVK = 0,60. Ini berarti PPKM level 4 yang diberlakukan di Kota B.Aceh berpengaruh mengurangi pergerakan kendaraan. Mengingat biasanya pergerakan kendaraan di Kota seharusnya setiap tahun ada kenaikan pergerakan arus lalu lintas.
\end{abstract}

Kata kunci : MKJI, Kinerja Jalan, T.Iskandar, TVK, Covid-19, PPKM Level 4

\section{Pendahuluan}

Perkembangan suatu kota menyebabkan bertambah banyaknya rumah penduduk, sehingga adanya suatu pergerakan lalu-lintas. Pergerakan lalu-lintas ini menimbulkan volume lalu lintas meningkat, pengguna jalan yang kurang disiplin, dan munculnya kemacetan pada kinerja arus lalu-

Journal of The Civil Engineering Student

Vol. 3. No. 3, Desember 2021, Halaman 222-227 lintas.

Sementara itu, khusus kepada Walikota Banda Aceh yang wilayahnya ditetapkan sesuai kriteria level situasi pandemi berdasarkan asesmen, dengan kriteria level 4 berdasarkan Diktum Kesatu huruf a Instruksi Menteri Dalam Negeri Nomor 31 Tahun 2021 tentang Pemberlakuan Pembatasan Kegiatan Masyarakat Level 4 Corona Virus Disease 
2019 (COVID-19) di Wilayah Sumatera, Kalimantan, Sulawesi, Nusa Tenggara, dan Papua, selain mengatur PPKM Mikro secara umum, juga secara khusus mengatur sebagaimana Diktum. Bulan Agustus 2021, Kota Banda Aceh sedang dalam keadaan zona merah, pada zona merah pemerintah harus melacak kontak erat, melakukan isolasi mandiri terpusat dengan pengawasan ketat dan menutup tempat bermain anak dan tempat umum lainnya kecuali sektor esensial. Kemudian mengatur pembatasan pelaksanaan ibadah dan kegiatan lainnya di rumah ibadah. Selanjutnya adalah pelarangan kerumunan lebih dari sepuluh orang, membatasi keluar masuk wilayah Gampong paling lama hingga pukul 22.00 malam dan meniadakan semua kegiatan sosial masyarakat di lingkungan Gampong yang berpotensi menimbulkan kerumunan dan berpotensi menimbulkan penularan. Tujuan penelitian ini adalah untuk mengetahui kinerja Jalan T.Iskandar terhadap pengaruh pemberlakukan PPKM level 4 di Kota Banda Aceh di bandingkan dengan keadaan normal.

\section{Tinjauan Kepustakaan}

\subsection{Kinerja Jalan}

Berdasarkan MKJI (1997) yang dikeluarkan oleh Direktorat Jendral Bina Marga, kinerja jalan merupakan suatu pengukuran kuantitatif yang menggambarkan kondisi tertentu yang terjadi pada suatu ruas jalan. Umumnya dalam menilai suatu kinerja jalan dapat dilihat dari volume lalu-lintas, kapasitas, rasio volume kapasitas, kecepatan aktual, waktu tempuh, tundaan dan antrian melalui suatu kajian mengenai kinerja ruas jalan.

\subsection{Jalan Perkotaan}

Anonim (2004 : 1) menyebutkan bahwa jalan perkotaan adalah jalan yang mempunyai perkembangan secara permanen dan menerus sepanjang jalan, minimum di satu sisi jalan, apakah berupa perkembangan lahan atau bukan, jalan di dekat perkotaan dengan penduduk lebih dari 100.000 jiwa selalu digolongkan dalam kelompok ini. Jalan di daerah perkotaan dengan penduduk kurang dari 100.000 jiwa digolongkan ke dalam jalan perkotaan apabila mempunyai perkembangan samping jalan yang permanen dan menerus.

\subsection{Karakteristik Arus Lalu Lintas}

Karakteristik arus lalu lintas perlu diketahui dan dipelajari untuk menganalisis arus lalu lintas. Untuk mempresentasikan karakteristik arus lalu lintas, maka dikenaki 3 parameter utama yang saling berhubungan secara matematis (Tamin, $2008: 23$ ), yaitu volume lalu lintas, kecepatan (speed), dan kepadatan (density).

\subsubsection{Volume Lalu Lintas (Q)}

Adapun volume lalu lintas menurut Bukhari dan Saleh (2002 : 20) diperoleh dengan pengamatan langsung dilapangan tentang jumlah kendaraan yang lewat pada periode tertentu (detik, menit, dan jam). Volume lalu-lintas ini juga berpengaruh terhadap waktu, komposisi lalu lintas, pembagian jurusan, klasifikasi fungsional jalan, jenis penggunaan daerah serta geometrik jalan. Adapun persamaan matematis volume lalu lintas ditetapkan sebagai berikut :

$$
Q=\frac{N}{t}
$$

Dimana :

$\mathrm{Q}=$ Volume lalu lintas dalam satuan kendaraan persatuan waktu;

$\mathrm{N}=$ Jumlah kendaraan yang melewati suatu penggal ruas jalan tertentu dalam

selang waktu tertentu; dan

$\mathrm{t}=$ Selang waktu peninjauan

\subsubsection{Faktor Konversi Kendaraan}

Ekivalensi mobil penumpang (emp) adalah faktor konversi berbagai jenis kendaraan dibandingkan dengan mobil penumpang dan kendaraan lainnya. Menurut MKJI (1997), nilai volume lalu lintas (Q) mencerminkan komposisi lalu lintas, dengan menyatakan satuan mobil penumpang (smp). Semua nilai arus lalu lintas (per arah dan total) diubah menjadi satuan mobil penumpang (smp) dengan menggunakan ekivalensi mobil penumpang (emp).

Jumlah kendaraan yang ada, kemungkinan terdapat di jalan raya antar kota, dapat dikelompokkan ke dalam 4 (empat) golongan. Keempat golongan tersebut, seperti terlihat dalam Tabel 2.1, masing-masing dikonversikan ke dalam satuan mobil penumpang (smp).

Tabel 1 Daftar Konversi ke Satuan Mobil Penumpang

\begin{tabular}{|c|c|c|c|}
\hline \multirow{2}{*}{$\begin{array}{c}\text { Tipe jalan } \\
:\end{array}$} & \multirow{3}{*}{$\begin{array}{l}\text { Arus lalu } \\
\text { lintas total } \\
\text { dua arah }\end{array}$} & \multicolumn{2}{|r|}{ Emp } \\
\hline & & & $\mathrm{MC}$ \\
\hline $\begin{array}{c}\text { Jalan tak } \\
\text { terbagi }\end{array}$ & & $\mathrm{HV}$ & $\begin{array}{c}\text { Lebar Jalur } \\
\text { Wc (m) }\end{array}$ \\
\hline
\end{tabular}


$\leq 6>6$

\begin{tabular}{ccccc}
\hline $\begin{array}{c}\text { Dua lajur } \\
\text { tak }\end{array}$ & 0 & 1,3 & 0,5 & 0,4 \\
terbagi & $\geq 1800$ & 1,2 & 0,35 & 0,25 \\
(2/2UD) & & & & \\
\hline Empat & & & & \\
lajur tak & 0 & 1,3 & 0,4 \\
terbagi & $\geq 3700$ & 1,2 & 0,25 \\
(4/2 UD) & & & \\
\hline
\end{tabular}

Sumber : MKJI (1997 : 5-38)

\subsection{Kapasitas Jalan (C)}

Menurut MKJI (1997 : 5-18), kapasitas didefinisikan sebagai arus maksimum melalui sesuatu titk di jalan yang dapat dipertahankan per satuan jam pada kondisi tertentu. Untuk jalan terbagi, analisis dilakukan terpisah pada masingmasing arah lalu lintas. Persamaan dasar kapasitas jalan perkotaaan yaitu :

$\mathrm{C}=\mathrm{Co} \times \mathrm{FCw} \times \mathrm{FCsp} \times \mathrm{FCsf} \times \mathrm{FCcs}$ ....(2)

Dengan :

$\mathrm{C}=$ Kapasitas $(\mathrm{smp} / \mathrm{jam})$

$\mathrm{Co} \quad=$ Kapasitas dasar ( $\mathrm{smp} / \mathrm{jam})$

$\mathrm{FCw}=$ Faktor penyesuaian akibat lebar jalan

FCsp = Faktor penyesuaian pemisah arah

FCsf = Faktor penyesuaian hambatan samping dan bahu jalan

FCcs = Faktor penyesuaian ukuran kota

Kapasitas dasar adalah kapasitas jalan pada kondisi geometrik, pola arus lalu lintas dan faktor lingkungan yang ditentukan sebelumnya (ideal). Kapasitas dasar ini ditentukan berdasarkan tipe jalan yang dapat dilihat pada Tabel 2.4.

\section{Tabel 2 Kapasitas Dasar Jalan Perkotaan}

\begin{tabular}{ccc}
\hline Tipe Jalan & Kapasitas Dasar & Catatan \\
\hline $\begin{array}{c}\text { Empat lajur } \\
\text { terbagi atau } \\
\text { jalan satu } \\
\text { arah }\end{array}$ & 1650 & Per lajur \\
\hline $\begin{array}{c}\text { Empat lajur } \\
\text { tak terbagi }\end{array}$ & 1500 & Per lajur \\
\hline $\begin{array}{c}\text { Dua lajur } \\
\text { tak terbagi }\end{array}$ & 2900 & Total dua arah \\
\hline
\end{tabular}

Sumber : MKJI (1997)

\subsection{Rasio Volume Kapasitas (RVK)}

Rasio volume kendaraan (RVK) adalah rasio arus lalu lintas terhadap kapasitas, digunakan sebagai faktor utama dalam penentuan tingkat kinerja simpang dan segmen jalan. Nilai RVK menunjukkan apakah segmen jalan mempunyai masalah kapasitas atau tidak (MKJI, 1997 : 5-19). Persamaan rumus digunakan sebagai berikut:

$$
\mathrm{RVK}=\mathrm{Q} / \mathrm{C} \text {. }
$$

Dimana :

RVK = Rasio volume kapasitas;

Q = Arus lalu lintas (smp/jam);

C = Kapasitas (smp/jam).

Untuk menghitung rasio volume kendaraan pada suatu ruas jalan perkotaan digunakan persamaan dalam MKJI (1997) yang dikeluarkan oleh Direktorat Jenderal Bina Marga. Dikarenakan jalan Teuku Iskandar termasuk kedalam jalan arteri primer, maka RVK untuk jalan arteri dan kolektor yaitu < 0,85 (Permen PU No. 19/PRT/M/2011).

\subsection{Kecepatan Arus Bebas (FV)}

Berdasarkan MKJI (1997 : 5-18), kecepatan arus bebas didefinisikan sebagai kecepatan pada tingkat arus nol, yaitu kecepatan yang dipilih oleh pengemudi jika mengendarai kendaraan bermotor tanpa dipengaruhi oleh kendaraan bermotor lainnya. Persamaan penentuan kecepatan arus bebas dapat digunakan persamaan dengan rumus berikut :

$\mathrm{FV}=(\mathrm{FVo}+\mathrm{FVw}) \times \mathrm{FFV}_{\mathrm{SF}} \times \mathrm{FFV}_{\mathrm{cs}} \ldots . .(2.4)$ Dimana ;

$\mathrm{FV}=$ Kecepatan arus bebas $(\mathrm{km} / \mathrm{jam})$;

$\mathrm{FVo}=$ Kecepatan arus bebas dasar $(\mathrm{km} / \mathrm{jam})$;

$\mathrm{FVw}=$ Penyesuaian lebar lajur lalu lintas jalan $(\mathrm{km} / \mathrm{jam})$;

$\mathrm{FFV}_{\mathrm{SF}}=$ Faktor penyesuaian hambatan samping dan lebar bahu; dan

FFVcs $=$ Faktor penyesuaian ukuran kota (jumlah penduduk).

\subsection{Kecepatan Tempuh $\left(\mathrm{FV}_{\mathrm{LV}}\right)$}

Menurut MKJI (1997 : 5-19), kecepatan tempuh dinyatakan sebagai ukuran utama kinerja suatu segmen jalan, karena hal ini mudah dimengerti dan diukur, kecepatan tempuh didefinisikan sebagai kecepatan rata-rata ruang dari kendaraan ringan (LV) sepanjang segmen jalan. Dengan hasil rasio volume kapasitas (RVK) dan kecepatan arus bebas $\left(\mathrm{F}_{\mathrm{V}}\right)$ yang didapatkan, maka dapat menentukan 
kecepatan tempuh dengan menggunakan gambar 2.1 (MKJI, 1997 : 5-58) berikut ini :

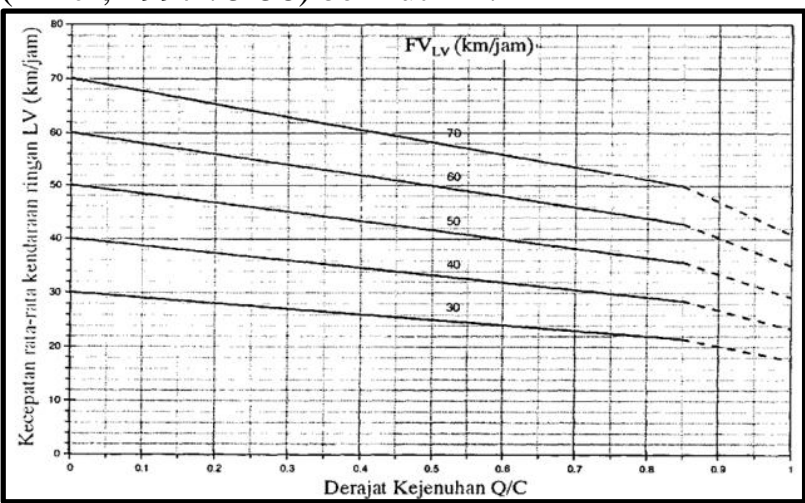

Gambar 2.1 : Kecepatan Sebagai Fungsi dari RVK untuk Jalan 2/2 UD

\subsection{Penelitian Terdahulu}

Berdasarkan penelitian yang pernah dilakukan oleh Nanda Muntashir Muzwar (2017) dengan judul "Analisis Kinerja Jalan Teuku Iskandar Banda Aceh Akibat Hambatan Samping” yang bertujuan untuk mengetahui pengaruh hambatan samping yang terjadi terhadap kinerja jalan. Peneletian ini meliputi perhitungan volume lalu lintas, kecepatan tempuh lalu-lintas, kecepatan arus bebas, kapasitas jalan dan rasio volume kapasitas akibat berkurangnya luas areal jalan karena adanya hambatan samping melalui beberapa skenario dan mengusulkan solusi pemecahan terhadapa permasalahan akibat faktor hambatan samping pada jalan Teuku Iskandar Kota Banda Aceh. Analisis data dilakukan dengan menggunakan Manual Kapasitas Jalan Indonesia (MKJI) 1997, penelitian ini menghasilkan kesimpulan sebagai berikut kapasitas jalan adalah sebesar $2401 \mathrm{smp} / \mathrm{jam}$, dan derajat kejenuhan sebesar 0,60 .

\section{Metode Penelitian}

Metode penelitian adalah langkah-langkah yang dilakukan secara sistematis dengan kerangka acuan yang jelas dalam menyelesaikan permasalahkan. Bab ini menjabarkan mengenai metode pengumpulan data dan pengolahan data.

Penelitian ini diawali dengan pengumpulan data primer dan data sekunder terlebih dahulu untuk selanjutnya dilakukan pengolahan data dan analisis data, kemudian dilanjutkan penyusunan kesimpulan beserta saran oleh peneliti.

Data yang diperlukan dalam penelitian ini berupa data primer dan data sekunder. Agar penelitian ini sesuai dengan tujuan, maka dibuat batasan-batasan seperti berikut ini :

1. Lokasi penelitian dilakukan di Jalan Teuku Iskandar dari Simpang BPKP menuju Simpang Tujuh Ulee Kareng, Kota Banda Aceh.
2. Survei lalu lintas dilakukan hanya tiga hari yaitu Senin (16 Agustus 2021), Rabu (18 Agustus 2021), dan Minggu (15 Agustus 2021) pada jam puncak pagi dan sore yaitu 07.0009.00 WIB dan 17.00-19.00 WIB.

3. Jenis kendaraan yang menjadi objek survei adalah sepeda motor $(\mathrm{MC}=$ Motor Cycle $)$, kendaraan ringan $(\mathrm{LV}=$ Light Vehicle $)$, dan kendaraan berat $(\mathrm{HV}=$ Heavy Vehicle) .

4. Analisis data dilakukan dengan menggunakan Manual Kapasitas Jalan Indonesia (MKJI) 1997.

\subsection{Pengumpulan Data Primer dan Skunder}

Data primer adalah data yang didapat dari hasil pengamatan langsung dilapangan. Survei di lapangan dilakukan dengan menggunakan kamera selama tiga hari yaitu pada hari Minggu, Senin, dan Rabu. Pemilihan survei pada hari Minggu, Senin, dan Rabu dikarenakan penelitian penilitian ini membuktikan bahwa kinerja Jalan Teuku Iskandar pada masa pandemi COVID-19 Level 4, apakah dalam keadaan normal atau tidak. Penelitian ini dilakukan di ruas jalan di depan Toko GARLAM pada jam puncak yaitu pada pukul 07.00-09.00 WIB dan 17.00-19.00 WIB. Adapun data yang langsung didapatkan di lapangan adalah geometrik jalan dan Komposisi arus lalu lintas.

Data sekunder adalah data yang diperoleh dari instansi-instansi terkait,

meliputi :

1. Peta Kota Banda Aceh dan Aceh Besar.

2. Jumlah penduduk Kota Banda Aceh dan Aceh Besar dari Badan Pusat Statistik (BPS) tahun 2016 dan 2019

3. Tingkat Pelayanan Jalan

\section{Hasil dan Pembahasan}

\subsection{Gambaran Lokasi Penelitian}

Jalan Teuku Iskandar yang ditinjau merupakan jalan dari Simpang BPKP menuju Simpang Tujuh Ulee Kareng, Kota Banda Aceh. Lokasi penelitian ini berada di Kecamatan Ulee Kareng, pada ruas Jalan Teuku Iskandar terdapat pertokoan, dan bengkel. Hasil pengamatan geometrik, jalan Teuku Iskandar bertipe dua lajur dua arah tak terbagi (2/2 UD) ini memiliki ruas jalan dengan panjang jalan \pm 3 kilometer, lebar badan jalan 8 meter, dan lebar bahu efektif 0,5 meter. 


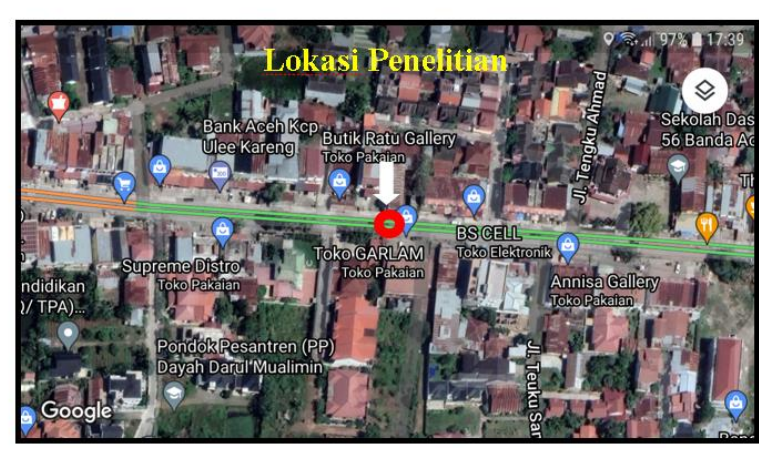

Gambar 2. Lokasi Penelitian

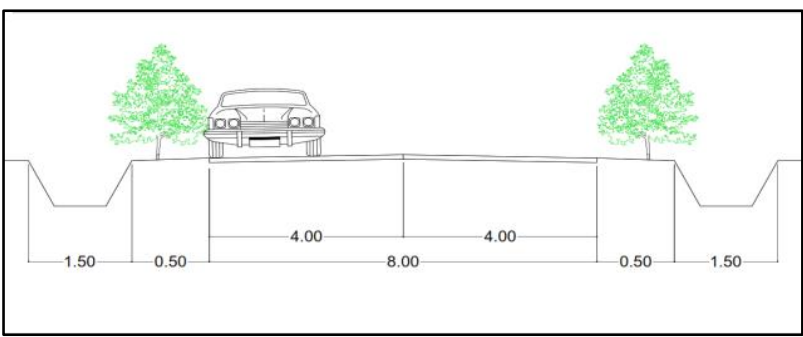

Gambar 3. Penampang Melintang Ruas Jalan Teuku Iskandar

\subsection{Volume Lalu Lintas}

Berdasarkan hasil pengolahan data yang diperoleh dilapangan, volume kendaraan tertinggi pada arus lalu lintas terjadi pada hari Senin 16 Agustus 2021 pukul 17.00-18.00 WIB sebesar $1645,7 \mathrm{smp} / \mathrm{jam}$. Adapun data hasil pengamatan volume lalu-lintas yang diperoleh selama tiga hari dapat dilihat pada Tabel 4.1, Tabel 4.2 dan Tabel 4.3 di bawah ini. Untuk data lebih lengkap volume lalulintas pada hari Senin, Rabu, dan Minggu dapat dilihat gambar di bawah ini.

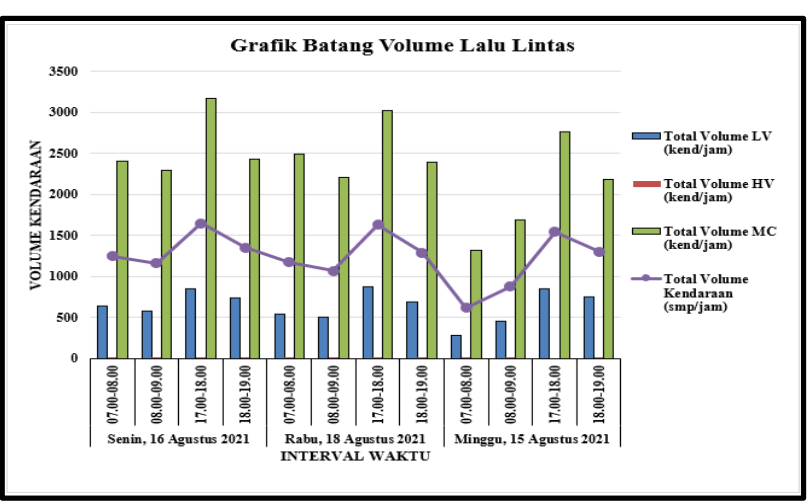

Gambar 4 : Grafik Batang Volume Lalu Lintas

\subsection{Kapasitas Jalan}

Tabel 3 Kapasitas Jalan

\begin{tabular}{ccccccc}
\hline & Kapasitas & \multicolumn{4}{c}{ Faktor penyesuaian untuk kapasitas } & \\
\cline { 3 - 6 } Hari & dasar & Lebar & Pemisah & Hambatan & Ukuran & Kapasitas \\
& Co & jalur & arah & samping & kota & C \\
& $($ smp/jam $)$ & Fcw & FCsp & FCsf & FCcs & $($ smp/jam) \\
\hline$[1]$ & {$[2]$} & {$[3]$} & {$[4]$} & {$[5]$} & {$[6]$} & {$[7=2 \times 3 \times 4 \times 5 \times 6]$} \\
\hline Senin & 2900 & 1,14 & 1 & 0,92 & 0,9 & 2737,37 \\
\hline
\end{tabular}

\begin{tabular}{|c|c|c|c|c|c|c|}
\hline \multirow[b]{2}{*}{ Hari } & \multirow{2}{*}{$\begin{array}{c}\text { Kecepat } \\
\text { an } \\
\text { arus } \\
\text { bebas } \\
\text { dasar } \\
\text { FVo } \\
(\mathrm{km} / \mathrm{jam} \\
\text { ) }\end{array}$} & \multirow{2}{*}{$\begin{array}{c}\text { Faktor } \\
\text { penyesu } \\
\text { aian } \\
\text { untuk } \\
\text { lebar } \\
\text { jalur } \\
\text { FV }_{\mathrm{W}} \\
(\mathrm{km} / \mathrm{jam} \\
)\end{array}$} & \multirow[b]{2}{*}{$\begin{array}{c}\text { Fvo+ } \\
\text { FVw } \\
(\mathrm{km} / \mathrm{j} \\
\mathrm{am})\end{array}$} & \multicolumn{2}{|c|}{$\begin{array}{c}\text { Faktor } \\
\text { penyesuaian }\end{array}$} & \multirow[b]{2}{*}{$\begin{array}{c}\text { Kecepatan } \\
\text { arus bebas } \\
\mathrm{FV} \\
(\mathrm{km} / \mathrm{jam})\end{array}$} \\
\hline & & & & $\begin{array}{c}\text { Hambat } \\
\text { an } \\
\text { samping } \\
\text { FFV }_{\text {SF }}\end{array}$ & $\begin{array}{c}\text { Ukura } \\
\text { n } \\
\text { kota } \\
\text { FFVc } \\
\text { s }\end{array}$ & \\
\hline [1] & [2] & [3] & $\begin{array}{c}{[4=2+} \\
3]\end{array}$ & [5] & {$[6]$} & {$[7=4 \times 5 \times 6]$} \\
\hline Senin & 44 & 3 & 47 & 0,96 & 0,93 & 41,96 \\
\hline
\end{tabular}

Berdasarkan pengolahan data, kapasitas dasar (Co) untuk jalan dua lajur dua arah tak terbagi $(2 / 2$ UD) sebesar $2900 \mathrm{smp} / \mathrm{jam}$, maka diperoleh kapasitas jalan pada hari Senin (16 Agustus 2021), Rabu (18 Agustus 2021) dan Minggu (15 Agustus 2021) pada kondisi jam puncak yaitu sebesar 2737,37 smp/jam.

\subsection{Rasio Volume Kapasitas}

Rasio volume kapasitas ini adalah rasio antara volume lalu lintas (Tabel 4.1, Tabel 4.2, dan Tabel 4.3) dengan kapasitas (Tabel 4.4). Berdasarkan hasil pengolahan data tersebut maka didapatkan rasio volume kapasitas (RVK) untuk tiga hari pengamatan. Rasio volume kapasitas terbesar diperoleh pada hari Senin (16 Agustus 2021) pukul 17.00-18.00 dengan $\mathrm{RVK}=0,60$, dimana kinerja jalan arteri dan kolektor (Permen PU No. 19/PRT/M/2011). Adapun perhitungan untuk rasio volume kapasitas dapat dilihat pada Tabel 4.5 dibawah ini.

Tabel 4 Rasio Volume Kapasitas

\begin{tabular}{cccc}
\hline Hari & $\begin{array}{c}\text { Arus lalu- } \\
\text { lintas } \\
(\mathrm{Q})\end{array}$ & $\begin{array}{c}\text { Kapasitas } \\
(\mathrm{C})\end{array}$ & $\begin{array}{c}\text { Rasio volume } \\
\text { kapasitas } \\
(\mathrm{smp} / \mathrm{jam})\end{array}$ \\
$\begin{array}{cccc}(\mathrm{smp} / \mathrm{jam}) \\
{[2]}\end{array}$ & {$[3]$} & {$[4=2 / 3]$} \\
\hline Senin & 1645,7 & 2737,37 & 0,60 \\
\hline
\end{tabular}

\subsection{Kecepatan Arus Bebas}

Berdasarkan pengolahan data maka didapat hasil perhitungan kecepatan arus bebas (FV) sebesar $41,96 \mathrm{~km} / \mathrm{jam}$.

\section{Tabel 5 Kecepatan Arus Bebas} jalan yang baik memiliki nilai RVK $<0,85$ untuk 


\subsection{Kecepatan Rata-rata Kendaraan Ringan}

Nilai rasio volume kapasitas (Tabel 4) dan kecepatan arus bebas (Tabel 5) sudah didapatkan, maka kecepatan tempuh dapat dari grafik dibawah ini adalah $33 \mathrm{~km} / \mathrm{jam}$.

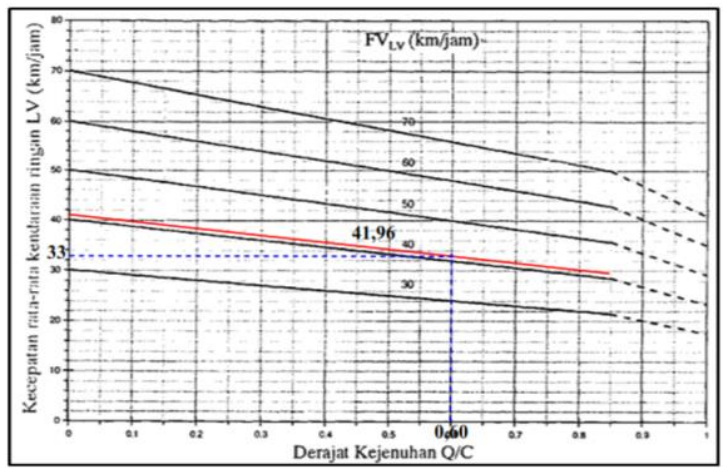

\section{Gambar 5 : Kecepatan Tempuh kendaraan} ringan

\subsection{Pembahasan}

Volume lalu-lintas tertinggi diantara ketiga hari pengamatan yaitu pada hari Senin tanggal 16 Agustus 2021, sebesar 1645,7 smp/jam pada jam puncak sore pukul 17.00-18.00 WIB. Pada hari Rabu volume lalu-lintas puncak terjadi pada jam puncak sore pukul 17.00-18.00 WIB sebesar 1631,25 smp/jam. Pada hari Minggu volume lalu-lintas puncak terjadi pada jam puncak sore pukul 17.0018.00 WIB sebesar 1540,75 smp/jam

Berdasarkan hasil pengolahan data hari Senin, kapasitas jalan sebesar 2737.37 smp/jam, Rasio volume kapasitas sebesar 0,60 (Tingkat pelayanan B), kecepatan arus bebas sebesar 41,96 $\mathrm{km} / \mathrm{jam}$, kecepatan tempuh sebesar $33 \mathrm{~km} / \mathrm{jam}$. RVK yang dihasilkan pada hari Senin $<0,85$ yaitu memenuhi persyaratan pada Permen PU no.19/PRT/M/2011.

Berdasarkan hasil pengolahan data hari Rabu, kapasitas jalan sebesar 2737.37 smp/jam, Rasio volume kapasitas sebesar 0,60 (Tingkat pelayanan B), kecepatan arus bebas sebesar 41,96 $\mathrm{km} / \mathrm{jam}$, kecepatan tempuh sebesar $33 \mathrm{~km} / \mathrm{jam}$. RVK yang dihasilkan pada hari Rabu $<0,85$ yaitu memenuhi persyaratan pada Permen PU no.19/PRT/M/2011 dan masih sama dengan hari Senin.

Berdasarkan hasil pengolahan data hari Senin, kapasitas jalan sebesar 2737.37 smp/jam, Rasio volume kapasitas sebesar 0,56 (Tingkat pelayanan A), kecepatan arus bebas sebesar 41,96 $\mathrm{km} / \mathrm{jam}$, kecepatan tempuh sebesar 33,5 km/jam. RVK yang dihasilkan pada hari Minggu $<0,85$ yaitu memenuhi persyaratan pada Permen PU
no.19/PRT/M/2011 dan juga lebih kecil dari pada hari Senin dan Rabu.

Oleh karena itu untuk saat ini belum diperlukan tindakan perbaikan atau pelebaran jalan pada jalan ini. Seiring dengan berjalannya waktu volume lalu-lintas kendaraan akan semakin meningkat yang diakibatkan oleh adanya peningkatan jumlah kendaraan bermotor setiap tahun, hal ini akan menyebabkan kapasitas pada jalan Teuku Iskandar setelah pandemi selesai dan beberapa tahun kedepan tidak mampu lagi melayani kendaraan yang melintas dengan nyaman karena nilai rasio volume kapasitas pada hari Senin dan hari Rabu sudah mulai mendekati 0,85 .

\section{Kesimpulan Dan Saran}

\subsection{Kesimpulan}

Dari hasil penelitian dan pengolahan data yang telah dilakukan maka dapat disimpulkan Rasio volume kapasitas terbesar dari tiga hari pengamatan diperoleh pada hari Senin tanggal 16 Agustus 2021 dengan nilai sebesar 0,60 sama dengan nilai RVK yang 2017 yang dilakukan penelitian oleh muzwar. Diperkirakan nilai DS yang sama karena PPKM level 4 terbukti mengurangi pergerakan masyarakat.

\subsection{Saran}

Diharapkan untuk penelitian selanjutnya dapat meneliti kinerja Jalan T.Iskandar dengan menghitung hambatan samping yang real dilapangan. Selajutnya dapat meneliti Jalan T.Iskandar pada saat pemberlakukan PPKM level 4 talah selesai.

\section{Daftar Kepustakaan}

[1] Anonim, 2004, Geometrik Jalan Perkotaan, Badan Standarisasi Nasional.

[2] BPS Kab. Aceh Besar Dalam Angka, Kab. Aceh dalam Angka 2019

[3] BPS Kota Banda Aceh Dalam Angka, Kota Banda Aceh dalam Angka 2019

[4] Bukhari R.A dan Saleh S.M., 2004, Rekayasa Lalulintas I, Fakultas Teknik Universitas Syiah Kuala, Darussalam, Banda Aceh.

[5] Dinas Lingkungan Hidup dan Kehutanan, 2021, Gubernur Aceh Perpanjang PPKM Hingga 23 Agustus

[6] Muzwar N.M, 2017, Analisis Kinerja Jalan Teuku Iskandar Banda Aceh Akibat Hambatan Samping, Fakultas Teknik Universitas Syiah Kuala, Darussalam, Banda Aceh.

[7] Peraturan Menteri Pekerjaan Umum Nomor 19/PRT/M/2011, Persyaratan Teknis Jalan Dan Kriteria Perencanaan Teknis Jalan, Menteri Pekerjaan Umum, Jakarta. 
[8] Qanun Kota Banda Aceh Nomor 2/2018, Perubahan Atas Qanun Kota Banda Aceh Nomor 4 Tahun 2009 Tentang Rencana Tata Ruang Wilayah Kota Banda Aceh Tahun 2009-2029, Pemerintah Kota Banda Aceh, Banda Aceh. 